\title{
STUDY ON DISTRIBUTION OF RHODODENDRON \\ ARBOREUM Sm. IN LANGTANG NATIONAL \\ PARK USING GEOGRAPHIC INFORMATION \\ SYSTEM AND REMOTE SENSING
}

\section{Ila Shrestha*}

\section{ABSTRACT}

The paper is based on the study of distribution of Rhododendron arboreum Sm. in Langtang National Park ranging from $600 \mathrm{~m}$ to $7234 \mathrm{~m}$. The study was carried out the Remote-Sensing and Geographic Information System technique. SPOT Image and ERDAS Software have been used for the image processing. The program has detected different ecological parameters in tropical to alpine zone and verified ground truth Rhododendron arboreum of the study.

Key Words: Rhododendron, geographic information system, remote sensing, national park

\section{INTRODUCTION}

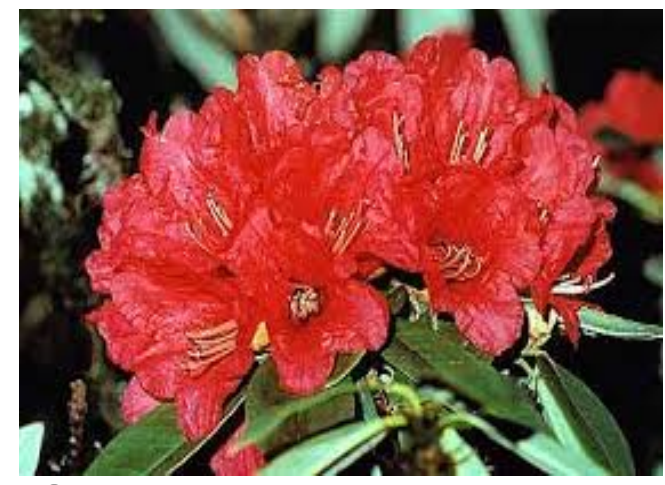

Rhododendron arboreum is a tree having height of around Rhododendron in English and Laliguras in Nepali, belonging to Ericaceae family. Its leaves are stalked crowded towards the end of branches, 4-16 $\mathrm{cm}$ long, 1.5-6 cm wide, oblong lanceolate, narrow at both ends, silvery beneath. Flowers are usually red and glorified as national flower of Nepal, fruits cylindrical capsules, longitudinally ribbed. Plants are propagated by seeds and cuttings. Flowering period is March-April and fruiting period is April-May. The species are found in western, central and eastern Nepal at 2800-3600 $\mathrm{m}$ in hilly open area. It also occurs in other parts of Himalaya (Kashmir to Arunanchal Pradesh). It is used for various purposes.

\footnotetext{
* Dr. Shrestha is Reader in Botany at Patan Multiple Campus, T.U., Lalitpur, Nepal
} 
Geographical Information System (GIS) is an efficient tool for collecting, storing, retrieving and displaying spatial data and also nonspatial data from the real world for a particular set of purposes. Remote sensing technique is a quicker, less expensive and more accurate method of survey compared to the conventional method.

\section{MATERIALS AND METHODOLOGY}

The SPOT (Satellite Pour I' Observation de la Terre) satellite data have been used during the research study. It is in the form of False Color Composite (FCC) having a resolution of $20 \mathrm{~m}$ sq. The SPOT uses spectral bands with the capability to discriminate plants. Satellite has three spectral bands so each pixel of SPOT satellite data consist three-file value. The SPOT uses four bands; among them the panchromatic band has stereo capability. The SPOT satellite has the best resolution amongst the other remote sensing satellites and its products have been selected for this study including the collection of ground information. The base map on 1:50,000 scale and 1: 25000 scale sheets have been prepared from the survey of the topography of Nepal. Supervised classifications have been done in long image process.

\section{GREEN BAND (BAND I)}

In the SPOT data of Green Band (Band 1) the minimum data file value is 23 and maximum data file is 72 . The data file values are grouped according to the following spectral ranges 23 to 27 (1); 28 to 32 (2); 33 to 37 (3); 38 to 42 (4); 43 to 47 (5); 48 to 52 (6); 53 to 57 (7); 58 to 62 (8); 63 to 67 (9); and 68 to $72(10)$.

\section{RED BAND (BAND 2)}

For the Red Band (Band 2), minimum spectral value is 12 and maximum spectral value is 76 . Pixels were grouped as spectral class according to the following spectral range 12 to 16 (1); 17 to 21 (2); 22 to 26 (3); 27 to 31 (4); 32 to 36 (5); 37 to 41 (6); 42 to 46 (7); 47 to $51(8)$; 52 to 56 (9); 57 to 61 (10); 62 to 66 (11); 67 to 71 (12); and 72 to $76(13)$.

\section{NEAR INFRARED BAND (BAND 3)}

For the Near Infrared Band (NIR) Band 3, minimum spectral value is 14 and maximum spectral value is 93 . Pixels were grouped as following spectral ranges, 14 to 18 (1); 19-23 (2); 24 to 28 (3); 29 to 33 (4); 34 to 38 (5); 39 to 43 (6); 44 to 48 (7); 49 to 53 (8); 54 to 58 (9); 59 to 63 (10); 64 to 68 (11); 69 to 73 (12); 74 to 78 (13); 79 to 83 (14); 84 to 88 (15) and 89 to 93 (16).

The supervised classification has been used to create training samples. The training samples are the sets of pixels recognized as potential classes. The statistics from the sample pixels have been calculated to create the signature of the classes. The signature of the training samples, have been derived based on spatially defined and species 
homogenous sample. The standard deviation of each sample is unique quantitatively and qualitatively for each class. Twenty nine sample plots were marked in the maps after image processing and identified in the field with the help of Topographic sheets and GPS. In the identified points 50 $\mathrm{m} \times 50 \mathrm{~m}$ quadrates were fixed for the study of ecological parameters.

Analysis of the satellite imagery has been carried out using visual image processing techniques by the Mountain Environment and Natural Resources' System (MENRIS) Division of the International Centre for Integrated Mountain Development (ICIMOD), Nepal. Black

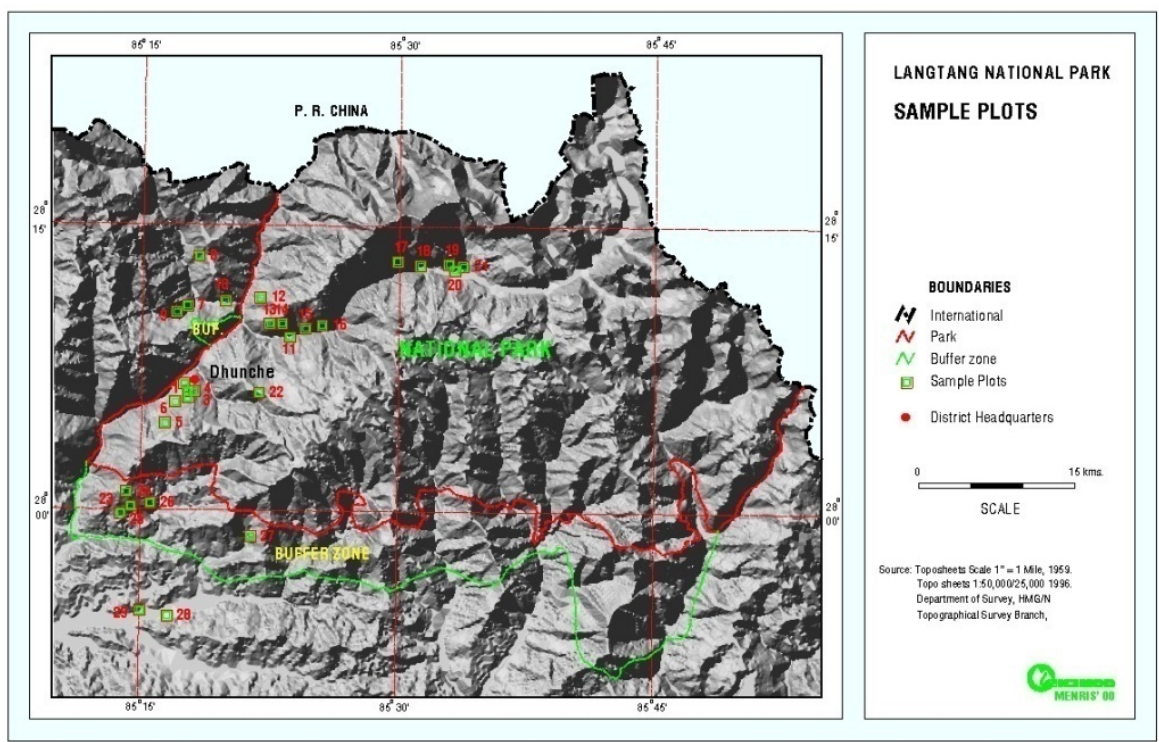

and white aerial photographs have been used as secondary data. Erdas Imagine 8.3.1 software was applied during the image processing.

\section{RESULTS AND DISCUSSION}

The spatially defined and spectrally homogenous field samples are spatial image segment which can identify biological units based on spectral homogeneity of individual spectral bands in the specific digital range and also field survey (Myint, 1996). Twenty nine points were marked in the spatially defined and spectrally homogeneous sample maps. I identified the accurate field with the help of topography maps, GPS and aerial photographic sheets for the study of ecological parameters. But Rhododendron arboreum was found distributed in eleven sample plots, 1 , $2,3,4,6,9,13,14,15,24$, and 26. Detail information of the species are given in each sample plot. 


\section{SAMPle Plot No. 1}

The spectral range of 49 to 53 in the near infrared identified Rhododendron arboreum in this plot lies in the Brabal jungle with an altitude $1950 \mathrm{~m}$ with longitude and latitude $85^{\circ} 17.34^{\prime} \mathrm{E}$ and $28^{\circ} 06.6^{\prime} \mathrm{N}$. Benthamidiacapitata and Viburnum coriaceum, Berberisaristata., Indigoferadosua, Lyoniaovalifolia, Pinusroxburghii, Pinuswallichiana, Prunuscerasoides, Pyruspashia, Symplocostheaefolia, Quercusincana, Quercuslanuginosa, Rhusjavanica, Semecarpusanacardium, Schimawallichii, Tsugadumosa were associated species.

\section{SAMPLE PLOT No. 2}

The spectral range of 57 to 61 in the Red Band identified Rhododendron arboreum in this plot that lies Dhunche city with an altitude $2320 \mathrm{~m}$ and longitude and latitude of this plot is $85^{\circ} 18.07^{\prime}$ and $28^{\circ} 06.2^{\prime}$, respectively. The associated tree species were Quercusincana and Linderapulcherrima, Alnusnepalensis, Benthamidiacapitata, Berberisaristata, Euryaacuminata, Lyoniaovalifolia, Pierisformosa, Prunuscerasoides, Quercussemecarpifolia and Tsugadumosa.

\section{SAMPLE PLOT No. 3}

The spectral range of 57 to 61 in the Red Band identified Rhododendron arboreum in this plot that lies in southern direction of Dhunche bazar with an altitude $1950 \mathrm{~m} ., 85^{\circ} 17.07^{\prime} \mathrm{E}$ longitude and $28^{\circ} 05.88^{\prime} \mathrm{N}$ latitude. It lies in the slope of $20.61^{\circ}$. Altogether 11 tree species were found in this plot. About $20 \%$ of the area was covered by Drapanostachyumfalcata and other species are Benthamidiacapitata, Berberisaristata, Betulaalnoides, Euryaceracifolia, Linderapulcherrima, Lyoniaovalifolia, Rhododendron arboreum, Quercusincana. Quercuslanuginosea, Quercussemecarpifolia and at $1950 \mathrm{~m}$.

\section{SAMPLE Plot No. 4}

The spectral range of 38 to 42 in the Green Band identified

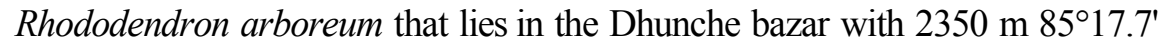
W longitude and $28^{\circ} 06.20^{\prime} \mathrm{N}$ latitude. Quercusincana, Lithocarpusgrandifoila, Euryaacuminata, and Benthamidiacapitata were dominant specie and other associated species were Berberisaristata, Betulautilis, Elaeagnusconferta, Indigoferadosua, Linderapulcherrima, Lyoniaovalifolia, Prunuscerasoides, Quercuslanuginosa, Quercussemecarpifolia, Rhododendron arboreum, Semecarpusanacardium, Symplocostheaefolia, Tsugadumosa, Viburnum coriaceum, and Viburnum mullaha.

\section{SAMPLE Plot No. 6}

The spectral range of 28 to 32 in the Red Band identified Rhododendron arboreum in the plot that lies in the Sole Jungle with an 
altitude of 2030 mand $85^{\circ} 16.96 \mathrm{E}$ and $28^{\circ} 05.67^{\prime} \mathrm{N}$. The plot was covered by Acer campbellii, Benthamidiacapitata, Berberisaristata, Elaeagnusconferta, Euryaceracifolia, Indigoferadosua, Linderapulcherrima, Lyoniaovalifolia, Prunuscerasoides, Quercusincana, Rhododendron arboreum, Rhododendron campanulatum, Symplocostheaefolia, Tsugadumosa and Viburnum mullaha.

\section{SAMPLE PLOT No. 9}

The spectral range of 57 to 61 in the Red Band identified Rhododendron arboreum in the plot that lies in the Barkhu locality near to Bremdang river with an altitude of $2100 \mathrm{~m}$. The longitude and latitude of this plot is $85817.00^{\prime} \mathrm{E}$ and $28^{\circ} 10.55^{\prime} \mathrm{N}$. About $40 \%$ area was covered by Pinuswallichiana and Pinusroxburghii. Other associated species were Alnusnepalensis, Benthamidiacapitata, Betulautilis, Lyoniaovalifolia, Pyruspashiaand Viburnum coriaceum.

\section{SAMPLE Plot No. 13}

The spectral range of 52 to 56 in the Red Band identified Rhododendron arboreum that lies in the Bhanjyanggaon with an altitude of $2700 \mathrm{~m}, 85^{\circ} 21.90^{\prime} \mathrm{E}$ and $28^{\circ} 11.06^{\prime} \mathrm{N}$. The Pinuswallichiana were a dominant species in this plot and associated species were Benthamidiacapitata, Pyruspashia, Rhododendron arboreum, Rhododendron campanulatum, Tsugadumosa, and Viburnum coriaceum.

\section{SAMPLE Plot No. 14}

The spectral range of 57 to 61 in the Red Band identified Rhododendron arboreum that lies in Sherpa gaonat an altitude of $2750 \mathrm{~m}$. with the longitude and latitude of this plot is $85^{\circ} 23.15^{\prime}$ and $28^{\circ} 09.81^{\prime}$ respectively. Rhododendron arboreum and Elaeagnusconferta were common species while Betulautilis, Lyoniaovalifolia, Pinuswallichiana and Pyruspashia were associated species.

\section{SAMPLE Plot No. 15}

The spectral range of 52 to 56 in the Red Band identified Rhododendron arboreum in the plot that lies in between Sherpa Gaon and Rimche. The plot is at an altitude of $2800 \mathrm{~m}$, and longitude or latitude $85^{\circ} 25.51^{\prime} \mathrm{E}$, and $28^{\circ} 09.5$ N. Pinuswallichiana was a dominant species with Alnusnepalensis and Elaeagnusconferta as associate species.

\section{SAMPLE PlOT No. 24}

The spectral range of 59 to 63 to 61 in the Infrared Band identified Rhododendron arboreum in the plot that lies at Lokyule with an altitude 2400 $\mathrm{m}$, and longitude or latitude $85^{\circ} 14.12^{\prime} \mathrm{E}$ and $28^{\circ} 00.83^{\prime} \mathrm{N}$. Lyoniaovalifolia was dominant species with associated species Abiesspectabilis, Berberisaristata, Euryaacuminata, Ilex dipyerna, Linderapulcherrima, Pierisformosa, Pinusroxburghii, Pyruspashia, Quercusincana, 
Quercuslanuginosa, Quercussemecarpifolia, Rhododendron arboreum, Semecarpusanacardium, Tsugadumosa and Viburnum coriaceum.

\section{SAMPle Plot No. 26}

The spectral range of 57 to 61 in the Infrared Band identified Rhododendron arboreum lies at Bansbhanjyang with an altitude of $1400 \mathrm{~m}$. The longitude and latitude of this plot is $85^{\circ} 15.56^{\prime} \mathrm{E}$ and $28^{\circ} 00.34^{\prime} \mathrm{N}$. Lyoniaovalifolia, was dominant species and associated with Alnusnepalensis, Berberisaristata, Careyaarborea, Castanopsisindica, Engelhardtiaspicata, Euryaceracifolia, Ficussemicordata, Osyriswightiana, Pinusroxburghii, Pyruspashia, Rhododendron arboreum, Rhusjavanica, Schimawallichii, Shorearobusta, Syzygiumcumini, Viburnum coriaceum and Woodfordiafruticosa.

\section{ACKNOWLEDGEMENTS}

I thankfully acknowledge Patan Multiple Campus, Tribhuvan University for providing me study leave, Department of National Parks and Wildlife Conservation for giving me permission to carry out the field study in Langtang National Park. Thanks are equally due to the International Centre for Integrated Mountain Development (ICIMOD), MENRIS Division for providing every possible technical and financial support on Remote Sensing and Geographic Information System.

\section{WORKS CITED}

Archibald, P.D. (1987). "GIS and Remote Sensing Data Integration." Geocarto International. Vol. 3, pp. 67-73.

Lillesand, T.M. and R.W. Kieffer (1979). Remote Sensing and Image Interpretation. Canada.

Manandhar, N.P. (2002). Plants and People of Nepal. USA: Timber Press, Inc. Portland, Oregon.

Myint, M. (1996). "The Use of Remote Sensing Data for Inventory on Biodiversity of National Parks: A Case Study of the Alaungdaw Kathapa National Park in Myanmar". A Ph.D. Dissertation Report. Bangkok: Asian Institute of Technology, School of Environment, Resource and Development.

Press, J.R., K.K. Shrestha and D.A. Sutton (2000). An Annotated Checklist of Flowering Plants of Nepal. Kirtipur: British Museum (Natural History) London and Central Department of Botany, T.U. 